\title{
ТАКСИС И КАУЗАЛЬНОСТЬ: ИНТЕГРАЛЬНЫЙ СЕГМЕНТ
}

\section{TAXIS AND CAUSALITY: INTEGRAL SEGMENT}

\section{Arkhipova}

Summary: The article deals with functional and semantic categories of taxis and causality in the aspect of their inter-categorical integration. The statements with prepositional deverbatives with taxis-forming prepositions of causal semantics bei, in, mit, durch, aus, wegen, vor, aufgrund, благодаря, ради, для, из-за, because, through, at, by, wegens, vanwege represent the integral segment of intersection functionally-semantic fields of taxis and causality. In statements with prepositional deverbatives in German, English, Dutch and Russian, various causal-taxis categorical situations of simultaneity are actualized, including conjugated temporal-causal-taxis, conditional-causal-taxis, and iterative-causal-taxis.

Keywords: functional-semantic field, taxis, causality, inter-categorical integration, integral segment, causal-taxis categorical situations, simultaneity.
$\mathrm{B}$ статье рассматривается вопрос межкатегориальной интеграции функционально-семантических категорий таксиса и каузальности. Они конституируют поликатегориальный семантический субкомплекс выделяемого нами вслед за А.В. Бондарко аспектуальнотемпорально-таксисного поликатегориального семантического комплекса, актуализируемого в высказываниях с предложными девербативами. Категория таксиса трактуется как полицентрическое функционально-семантическое поле (ФСП), формируемое взаимодействующими друг с другом языковыми единицами разных уровней (морфологического, лексико-грамматического, синтаксического) $[1 ; 2 ; 3 ; 4 ; 6 ; 7]$.

Категория каузальности или каузальной обусловленности освещается в работах современных исследователей, трактующих данную категорию как разновидность полицентрического гетерогенного функционально-семантического поля логической или каузальной обусловленности в разноструктурных языках (русском, немецком, английском, казахском и др.) (И.С. Калятин, Г.А. Калмыкова, Т.А. Кожетьева, А.В. Бакулев и др.) [5; 8; 9; 10]. Т.А. Кожетьева рассматривает каузальность как функционально-семантическую, мыслительную и логическую категорию, а также как категорию, актуализируемую в речи и отражающую отношение субъекта к окружающей действительности [8, с. 30]. По мнению А.В. Бакулева, функционально-семантическое поле (ФСП) каузальности представляет собой разнообразную группировку
Архипова Ирина Викторовна к.филол.н., профессор, Новосибирский государственный педагогический университет irarch@yandex.ru

Аннотация: В статье рассматриваются функционально-семантические категории таксиса и каузальности в аспекте их межкатегориальной интеграции. Обследованные высказывания с предложными девербативами с таксисообразующими предлогами каузальной семантики bei, in, mit, durch, aus, wegen, vor, aufgrund, благодаря, ради, для, из-за, because, through, at, by, wegens, vanwege репрезентируют интегральный сегмент пересечения функционально-семантических полей таксиса и каузальности. В высказываниях с предложными девербативами в немецком, английском, нидерландском и русском языках актуализируются различные каузально-таксисные категориальные ситуации одновременности, в том числе, сопряженные темпорально-каузально-таксисные, кондиционально-каузально-таксисные и итеративно-каузально-таксисные.

Ключевые слова: функционально-семантическое поле, таксис, каузальность, межкатегориальная интеграция, интегральный сегмент, каузально-таксисные категориальные ситуации, одновременность.

синтаксических, морфологических и лексических единиц, выражающих семантическую категорию каузальности. Данная категория включает в себя категории причины, следствия, цели и уступки, а также мини- или субполя причины и следствия с соответствующими причинно-следственными отношениями [5, с. 98].

Согласно исследованиям Г.А. Калмыковой, ФСП каузальной обусловленности (каузальности) основывается на рассмотрении языковых явлений от значения (причинно-следственная зависимость) к форме (эксплицитные, эксплицитно-имплицитные и имплицитные способы выражения) на основе логической импликации $A \pm B$ («если A, то В» или «A по причине В»). Бинома каузальной обусловленности объединяет разноуровневые элементы в единое функционально-семантическое поле (ФСП) [9, с. 237-248]. ФСП поле каузальности включает в себя различные языковые средства (лексического, грамматического и др. уровней), обладающие разным функциональным потенциалом. Центральные (ядерные) компоненты ФСП каузальности являются эксплицитными средствами языковой репрезентации данной категории, в то время как периферийные компоненты представляют эксплицитно-имплицитную или имплицитную каузальность [10, с. 96-100].

В качестве ядерных (центральных) компонентов ФСП каузальности следует рассматривать сложноподчиненное предложение с придаточными причины с союзами 
weil/da, zumal/umso mehr als, noтому что, в связи с тем что, because и др., выполняющими функцию обстоятельства причины [10, с. 96-100]. В качестве периферийных компонентов ФСП каузальности рассматриваются: сложносочиненное предложение (с союзом denn и соединительным наречием nämlich в немецком языке), а также причастные, герундиальные, инфинитивные, деепричастные и предложно-субстантивные конструкции с предлогами каузальной семантики (из-за, благодаря, wegen, aus, vor, aufgrund, durch, because, thanks и др.). Особый исследовательский интерес представляют предложноименные группы на основе девербативов и деадъективов в составе простого и осложненного предложений, а также лексемы с семантикой каузации (в частности, каузативные глаголы) и имена существительные с семантикой каузальности.

Каузальный таксис в высказываниях с предложными девербативами трактуется нами как секундарная одновременность соотносимых между собой в рамках целостного временного периода действий, процессов, событий девербативов и глагольных предикатов, осложненная элементами каузальной обусловленности [1; $2 ; 3$; 4]. В немецком языке к прототипическим элементам каузально-таксисного синтагматического контекста одновременности следует относить:

(1) таксисообразующие предлоги, маркирующие каузальный таксис одновременности:

(а) политаксисные предлоги bei, in, mit, unter, durch в каузальном значении;

(б) монотаксисные каузальные предлоги aus, wegen, vor, aufgrund: Nun verlangsamt sich ihr Wachstum aufgrund der Abschwächung der Exporte; Wegen der Erhöhung der Kitagebühren sind im vergangenen Jahr tausende Eltern auf die Straße gegangen.

(2) лексемы со значением каузальности/каузации, в частности, каузативные глаголы целенаправленного (физического, интеллектуального, психического) воздействия: Später strebte die Tante gegen inn einen Prozess wegen Vergewaltigung an; Der Russe wurde auf die Polizeiwache gebracht und wegen schweren Raubüberfalls angeklagt [11];

(3) акциональные, процессуальные и статальные девербативы (das Eingreifen, die Abschwächung, die Erhöhung, die Vergewaltigung, der Raubüberfall, die Verzögerung, die Beschimpfung, die Beschuldigung, die Anerkennung, die Verzweiflung, die Aufregung, die Anstrengung, die Begeisterung, die Befürchtung, die Bewunderung, die Erregung, die Verzweiflung, die Verwunderung, das Zweifeln): Durch das Eingreifen Russlands in dem Konflikt wendete sich das Blatt zugunsten des syrischen Machthabers Baschar al-Assad; Fünf Rapper aus dem Umfeld der Berner Reitschule sind wegen Beschimpfung von SVP-Nationalrätin Natalie Rickli vom Regionalgericht Bern-Mittelland ver- urteilt worden; Das Spiel war wegen Verzögerung bei der Anreise der Gästefans mit einer halben Stunde Verspätung angepfiffen worden; In ihrer Verzweiflung ruft sie Charlie an und spricht ihm auf die Mailbox. (LC); Die Initiative «Pro Mosel» hatte im Dezember wegen Zweifeln an der Standsicherheit Strafanzeige gestellt [11].

Сопутствующее действие (процесс, состояние) девербатива рассматривается при этом как некоторая причина или основание для осуществления основного действия (процесса) глагольного предиката. При наличии в высказываниях с каузальными предлогами aus, vor, in, wegen, mit, bei, durch, aufgrund статальных и процессуальных девербативов (die Empörung, die Aufregung, die Erregung, die Begeisterung, die Bewunderung, die Verzweiflung, die Verwunderung, die Befürchtung, das Zweifeln, das Staunen, das Entsetzen) актуализируется каузально-таксисная семантика одновременности глагольного действия и эмоционального (психического, физиологического) состояния субъекта. Ср.

Mit Brüssel steht Orban seit Jahren im Konflikt wegen Zweifeln an der Rechtsstaatlichkeit seiner Politik.

Es kommt ihm nicht darauf an, dass wir vor Staunen und Bewunderung Mund und Nase aufreißen.

Amerika kocht aus Empörung über das zeitweilig extreme Vorgehen weißer Polizisten gegen Schwarze.

In seiner Aufregung vergaß der Mann allerdings die Handbremse zu ziehen [11].

Прототипические элементы каузально-таксисного синтагматического контекста в высказываниях с предложными девербативами репрезентируют интегральный сегмент пересечения взаимодействующих функционально-семантических полей таксиса и каузальности. Каузально-таксисные категориальные ситуации одновременности актуализируются в немецких высказываниях с предложными девербативами с политаксисными предлогами bei, in, mit, unter, durch в каузальном значении и монотаксисными каузальными предлогами aus, vor, aufgrund, wegen. Например:

Aufgrund der Verzögerung durch die fehlerhafte Bewertung seien ihm aber Einkünfte entgangen, erklärte der Kläger.

Die Ortschaftsräte befürworten die Veränderung auch aufgrund der Belebung des Wettbewerbs.

Auf zwei Männer kommen Strafanzeigen wegen des Fahrens unter Drogeneinfluss zu.

Das Spiel war wegen Verzögerung bei der Anreise der Gästefans mit einer halben Stunde Verspätung angepfiffen worden [11].

При наличии итеративных квантификаторов (атрибутов и адвербиалов интервала, частотности, узуальности, счетного комплекса, цикличности и др.) актуализируются сопряженные или синкретичные итеративно-каузаль- 
но-таксисные категориальные ситуации одновременности. Ср.:

Vor allem im ersten Bezirk rund um den Ring wird es aufgrund des royalen Besuches immer wieder temporär zu Straßensperren kommen.

Jeder, der ihn erstmals zu Gesicht bekommt, staunt vor Verwunderung [11].

Гетерогенность семантики политаксисных предлогов bei, unter и особенности лексико-семантического состава высказываний с предложными девербативами могут детерминировать актуализацию синкретичных таксисных значений одновременности, в частности, темпоральнокаузально-таксисных, кондиционально-каузально-таксисных и др. Ср.:

Bei diesem Anblick rückt die Melone doch glatt in den Hintergrund.

Beim Lesen des Romans bekommt man einen dicken Kloß im Hals.

Unter der Beschuldigung, sie würden dort herumlungern und den Anwohnern und Touristen der Stadt unerwünschte Dienstleistungen anbieten, wurden die Verhafteten auf das Polizeirevier in der Soi 9 gebracht [11].

В русских высказываниях с предложными девербативами с предлогами каузальной семантики благодаря, ради, для, из-за, в силу актуализируются каузально-таксисные категориальные ситуации одновременности. Например:

Доктор, походя и, вероятно, совсем не желая, оказался в оппозиции, довольно агрессивной, в силу непонимания, если судить по Сорби.

В силу уменьщения своей кинетической энергии существенно меньшее число молекул воды стремится покинуть жидкую фазу .... .

Благодаря его приезду рабочие лишены были своевременно обеда.

Ради изучения края был я в гостях у многих Фермеров ... [12].

В английском языке каузально-таксисные категориальные ситуации одновременности актуализируются при употреблении монотаксисных каузальных предлогов because, through и политаксисных предлогов каузальной семантики at и by. Например:

Fat Sam's nightclub is hidden behind a book shop, because of prohibition.
Through this observation, the artist finds himself in the midst of a fantastical mystery that captivates him and fuels him.

They both turned at my intrusion, and I stopped talking mid sentence and stared.

Many students and Laval University staff were shaken by the intrusions and the assaults [11].

В высказываниях нидерладского языка актуализируются каузально-таксисные категориальные ситуации при употреблении таксисообразующих предлогов каузальной семантики wegens, vanwege. Например:

Hij zit een langdurige straf uit wegens de beroving en de verkrachting van een bejaarde vrouw.

Zo werden in juni twee baptisten veroordeeld tot een hoge boete wegens het zingen van religieuze liederen.

De chatroom is verwijderd wegens te weinig belangstelling.

Verwarring, want het arbitrale duo lijkt het punt eerst af te keuren wegens lopen, maar besluit dan dat de score telt.

Vanaf die dag is het overdekte zwembad De Veluwehal gesloten wegens een verbouwing.

Hierop kreeg hij een bekeuring wegens het beledigen van een ambtenaar in functie.

Buiten zijn schuld raakt hij betrokken bij een aantal rampzalige gebeurtenissen, die eindigen met een veroordeling wegens afpersing [11].

Итак, межкатегориальная интеграция функционально-семантических категорий таксиса и каузальности детерминирует актуализацию каузально-таксисных категориальных ситуаций одновременности в разноструктурных языках. В высказываниях с предложными девербативами репрезентируются различные каузально-таксисные категориальные ситуации одновременности, в том числе, сопряженные темпорально-каузально-таксисные, кондиционально-каузально-таксисные и итеративно-каузально-таксисные. Немецкие, английские, нидерландские и русские высказывания с таксисообразующими (поли- и монотаксисными) предлогами каузальной семантики репрезентируют интегральный сегмент пересечения функционально-семантических полей таксиса и каузальности. Поли- и монотаксисные предлоги каузальной семантики bei, in, mit, durch, aus, wegen, vor, aufgrund, благодаря, ради, для, из-за, because, through, at, by, wegens, vanwege маркируют каузальнотаксисную семантику одновременности.

ЛИТЕРАТУРА

1. Архипова И.В. Синкретизм в сфере актуализации таксисных значений одновременности // Современная наука: актуальные проблемы теории и практики. Серия «Гуманитарные науки». 2019. № 12-2. С. 149-154.

2. Архипова И.В. Функциональный потенциал девербативов и его реализация в контексте // Евразийский гуманитарный журнал. 2020. № 1. С. 74-87.

3. Архипова И.В. Функциональная нагрузка девербативов в разноструктурных языках // Евразийский гуманитарный журнал. 2020. № 3. С. 4-12.

4. Архипова И.В. Предложные девербативы и их функционально-семантический потенциал // Инновационное развитие науки: возможности, проблемы, 
перспективы. Монография. М.: Перо, 2020. С. 115-133.

5. Бакулев А.В. Функционально-семантическое поле каузальности в современном русском языке. Автореф. дис. ... канд. филол. наук. Таганрог, 2009. 24 с.

6. Бондарко А.В. Общая характеристика семантики и структуры поля таксиса // Теория функциональной грамматики: Введение, аспектуальность, временная локализованность, таксис. Изд. 6-е. М.: Либроком, 2011. С. 234-242.

7. Бондарко А.В. Категоризация в системе грамматики. М.: Языки славянских культур, 2011а. 488 c.

8. Кожетьева Т.А. Поле каузальности в немецком языке // Иностранные языки в высшей школе. 2014. № 3. С. 30-33.

9. Калмыкова Г.А. Ближняя периферия функционально-семантического поля каузальной обусловленности // Вестник Челябинского государственного педагогического университета. 2013. № 12-2. С. 237-248.

10. Калятин И.С. Поле обоснования в немецком языке и грамматические средства его выражения // Филологические науки. Вопросы теории и практики. 2016. № 7 (61). 4. 3. С. 96-100.

11. Лаборатория корпусной лингвистики Лейпцигского университета. URL: http://www.wortschatz.uni-leipzig.de (дата обращения: 14.08. 2020).

12. Национальный корпус русского языка. URL: http://www.ruscorpora.ru (дата обращения: 14.08. 2020).

(с) Архипова Ирина Викторовна (irarch@уandex.ru).

Журнал «Современная наука: актуальные проблемы теории и практики»

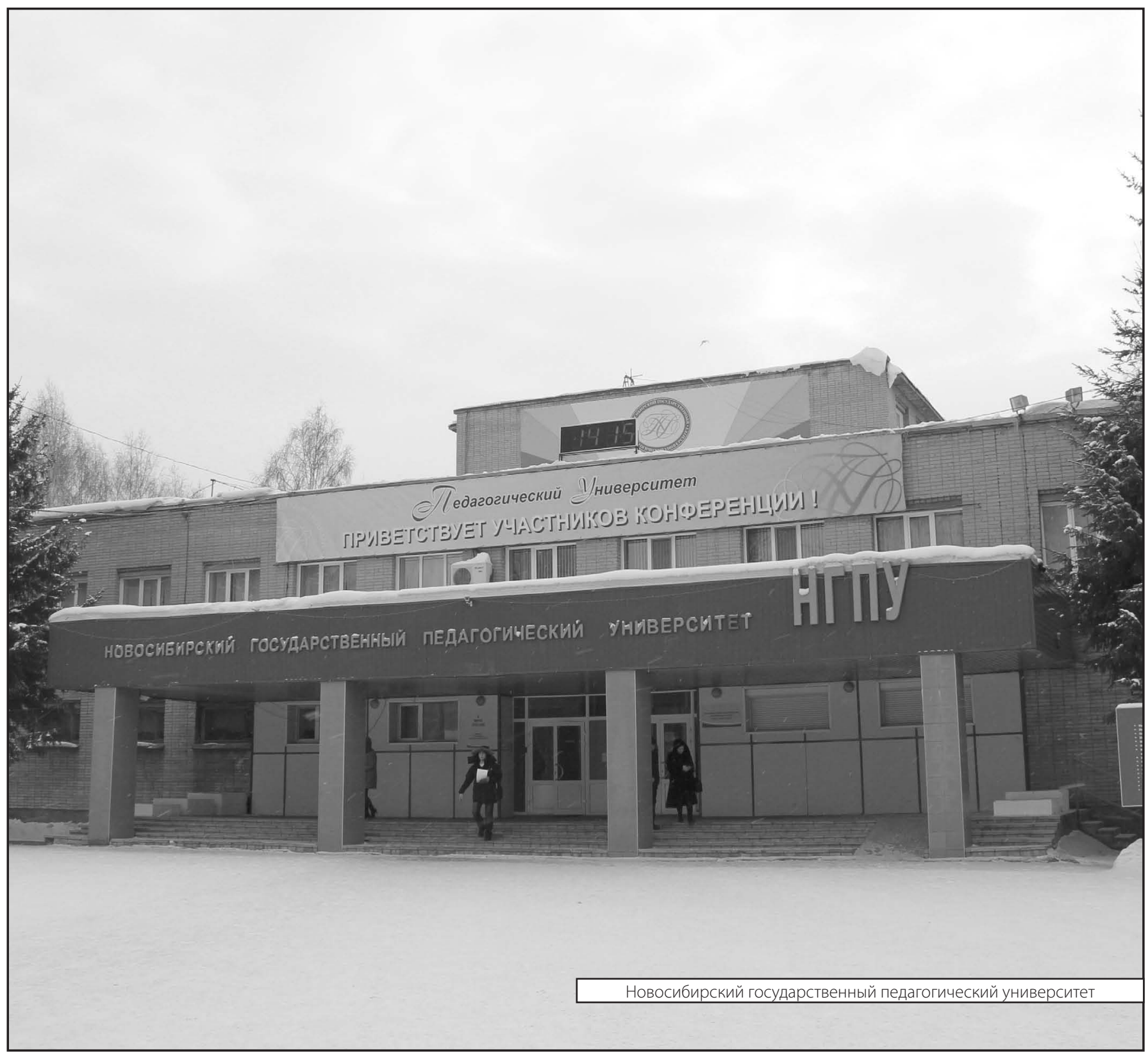

